\title{
BMJ Global Health Gender disparities in the experience, effects and reporting of electronic aggression among secondary school students in Nigeria
}

\author{
Adesola O Olumide, Emmanuel Adebayo, Babatunde Oluwagbayela
}

To cite: Olumide AO, Adebayo E, Oluwagbayela B. Gender disparities in the experience, effects and reporting of electronic aggression among secondary school students in Nigeria. BMJ Global Health 2016;1: e000072. doi:10.1136/ bmjgh-2016-000072

- Additional material is available. To view please visit the journal (http://dx.doi.org/ 10.1136/bmjgh-2016000072).

Received 21 April 2016 Accepted 25 August 2016

CrossMark

Institute of Child Health, College of Medicine, University of Ibadan, Ibadan, Oyo, Nigeria

Correspondence to Dr Adesola 0 Olumide; daisyolu@yahoo.co.uk

\section{ABSTRACT}

Background: Electronic aggression is the use of electronic communication technologies to harass others. It is a problem among adolescents and young people worldwide. There is a dearth of information on this problem in developing countries in spite of the increasing use of electronic media technology in these countries.

Objective: To explore gender differences in the prevalence, effects and reporting of electronic aggression among secondary school students in Oyo state, Nigeria.

Methods: A cross-sectional study was conducted using mixed methods (a quantitative survey of 653 students and 18 in-depth interviews with victims and/ or perpetrators). Survey students were selected using multi-stage sampling and in-depth interviewees were selected purposively. History of electronic aggression (as a perpetrator and/or victim) in the 3 months preceding the study was obtained. Respondents also provided information on the effects of the last incident of bullying on them and whether or not they reported this incident.

Results: $25.8 \%$ of males and $22.1 \%$ of females had perpetrated electronic aggression, while $42.7 \%$ of females were victims compared to $36.8 \%$ of males. More females $(58.1 \%)$ than males $(40.3 \%)$ perpetrated electronic aggression via phone calls and more males (33.8\%) than females $(22.6 \%)$ perpetrated electronic aggression via chatrooms. $45.4 \%$ of male victims and $39.4 \%$ of female victims felt angry following the last cyberbully incident. Findings from the in-depth interviewees corroborated the survey findings and a male victim reported feeling very sad and even tried to stay away from school following repeated episodes of electronic aggression. More female (59.1\%) than male $(42.7 \%)$ victims reported the incident to someone $(\mathrm{p}=0.035)$.

Conclusions: Incidents of electronic aggression were common and the experiences of male and female students were comparable, although more female victims reported the incidents they had experienced. Victims, especially males, should be encouraged to report incidents so that the relevant authorities can institute interventions to address the problem.

\section{Key questions}

What is already known about this topic?

- Electronic aggression is a problem among secondary school students.

What are the new findings?

- Slightly more females than males were victims of electronic aggression, although similar proportions of males and females were perpetrators.

- Females are more likely to report incidents of electronic aggression than males, although both sexes often choose to report to a peer who is close to them.

Recommendations for policy

- There is an urgent need to improve awareness of electronic aggression among parents, teachers, healthcare professionals and also adolescents.

- Adolescent health workers in clinic settings need to enquire about a history of electronic aggression when attending to the adolescents.

- The acronym that guides assessment of adolescents in healthcare settings-HEEADSSS (Home environment (including availability of cell phones and computers), Education and employment (including bullying problems), Eating, peer-related Activities, Drugs, Sexuality, Suicide/ depression, and Safety from injury and violence) -is a useful aid for obtaining information on cyberbullying.

\section{INTRODUCTION}

Globally, access and utilisation of mobile technologies is on the increase, ${ }^{1-4}$ especially among adolescents and young people ${ }^{5}$ and this places them at high risk of the negative effects associated with their use. One such negative effect is the risk of aggression and other violent behaviours perpetrated via electronic media. A 2009 brief from the Centers for Disease Control and Prevention (CDC) specified, that, "although many different 
terms, such as 'cyberbullying', 'Internet harassment', and 'Internet bullying', have been used to describe this type of violence, the term 'electronic aggression' most accurately captures all types of violence that occur electronically". ${ }^{6}$ Dooley et al describe cyber-aggression as all forms of aggressive behaviour including stalking, bullying and harassment which take place online and includes repeated and unrepeated acts that are likely to cause harm to the victim(s). In this paper, we use the term 'electronic aggression' as described in the CDC issue brief. ${ }^{6}$

Generally, extant research findings reveal that the prevalence of electronic aggression among adolescents and young persons varies widely with rates ranging from about $4 \%$ to as high as $33 \%$. Kowalski and Limber ${ }^{8}$ reported that among their sample of grade 6 to 8 students in the USA, $4.1 \%$ had been victimised and $6.8 \%$ had perpetrated electronic aggression at least once in the 2-month period preceding their study. Novo et a $t^{9}$ reported a prevalence of $33.3 \%$ in their sample of 12- to 16-year-olds in Portugal. In Nigeria, findings from a pilot study among secondary school students revealed that $33.9 \%$ of the students were victims of electronic harassment and $15.0 \%$ had harassed others at least once in the 3-month period preceding the pilot. ${ }^{10}$

Factors such as older age, high frequency of internet use and proficiency of mobile technology have been associated with electronic aggression among adolescents. ${ }^{8} 11 \quad 12$ Another factor reported to be associated with electronic aggression is gender. Gender has been described as "the social behaviours, lifestyle, and personality characteristics that women and men are expected to exhibit" ${ }^{13}$ Some researchers have reported significant associations between gender and various health behaviours, health outcomes and help-seeking behaviours among adolescents and adults. ${ }^{14-17}$ Although the association between gender and health is somewhat complex ${ }^{18}$ a number of theories such as the sex role theory of socialisation and social constructionist theory have been put forward to explain notions of gender and how this influences health. The sex role theory of socialisation describes gender as 'fixed' and categorises individuals as either feminine or masculine. ${ }^{19} 20$ This theory has been critiqued because gender is not static, especially as its expression changes over time and between cultures. ${ }^{19}$ The social constructionist theory explains that women and men think and behave in certain ways because of the concepts about femininity and masculinity that they adopt from experiences with their family, peers, community, etc, while growing up. For example, males are expected to display strength, to be aggressive, suppress their needs and refuse to admit or acknowledge their pain. ${ }^{19} 21$ Females are expected to be caring, always available to attend to the needs of others and avoid conflict, etc. ${ }^{1921}$

Research has shown a fairly consistent association between gender and traditional physical bullying, with many researchers reporting that males are more likely than females to perpetrate physical aggression and bullying, ${ }^{22}$ while females engage more in indirect forms of bullying such as psychological/relational bullying, emotional harassment and verbal aggression (eg, gossiping) ${ }^{23-25}$ Since electronic aggression is viewed as a form of relational bullying, it could be assumed that females would engage more in electronic aggression than males. Research findings on the association between gender and electronic aggression are, however, varied. ${ }^{8}{ }^{12}$ 25-28 Some researchers have found no association between gender and electronic aggression, ${ }^{10}{ }^{29}$ while others have reported that girls perpetrate electronic aggression more frequently than boys. ${ }^{8}$ Novo et at reported that more boys than girls in their sample perpetrated electronic aggression. Similarly, Barlett and Coyne ${ }^{30}$ in a recent meta-analysis reported that males were slightly more likely to be perpetrators of electronic aggression than females, although this association was moderated by age with females being more likely to be perpetrators in early adolescence while males were more likely to be perpetrators in late adolescence. A possible reason suggested for the discrepancy in the association between gender and electronic aggression is that males are often more proficient in the use of the newer media technology than females, ${ }^{31}$ and this might account for the higher prevalence of electronic aggression among males. In addition, perpetrators are also able to hide their identity when in cyberspace and this might make it difficult to identify the perpetrator's gender.

A few researchers have examined gender differences in effects of electronic aggression on victims and results have also been varied. For example, Beran and $\mathrm{Li}^{32}$ found no gender differences in the effect of electronic aggression on their victims. Ybarra ${ }^{33}$ reported a significant association between depressive symptoms and history of internet harassment among males but no association among females. Research findings on gender differences in reporting of electronic aggression are similarly diverse, although some researchers indicate that females are more likely to report incidents of electronic aggression than males. ${ }^{34}$

Electronic aggression has been largely studied among various population groups in developed countries, with few researchers reporting on its occurrence among adolescents in developing countries in Asia and Africa. ${ }^{35-37}$ This is in spite of the increasing use of electronic media (cellphone and internet) globally and in Nigeria. ${ }^{1-4} 3839$ Recent data from Internet World Stats (IWS) revealed that there were more than 97 million internet subscribers in Nigeria (approximately $52 \%$ of the total population) as of September 2015. ${ }^{40}$ With the growing attention on the potential to utilize newer media and communication technologies to deliver health interventions to adults and adolescents alike, ${ }^{41} 42$ the existing evidence of negative effects associated with the use of these technologies, and the fact that gender has been shown to play a role in health and other behaviours, it is important to investigate the association between gender 
and electronic aggression. These issues formed the basis for this paper.

We sought to determine if there would be significant gender differences in: (1) the prevalence of electronic aggression; (2) effects of the last incident of electronic aggression experienced; and (3) reporting of incidents of electronic aggression to authority figures in Oyo state, Nigeria. Our aim was to contribute to the existing literature on the association between gender and electronic aggression, to provide useful information to inform policy and practice in addressing the problem of electronic aggression in our society, and to identify which gender should be targeted with interventions against electronic aggression.

\section{METHODS}

(Please see online supplementary file I for a detailed version of the methods section).

\section{Study design}

A mixed methods approach ${ }^{43}$ utilising an explanatory sequential design ${ }^{44}$ was employed.

\section{Study area}

The study took place in Oyo state, south western Nigeria. ${ }^{45}$

\section{Participants}

\section{Quantitative}

These comprised students in selected secondary schools in rural and urban areas of Oyo state, Nigeria. Eligible students were those who owned a cellphone (mobile phone) and had been using this for a minimum of 6 months before the study and/or students who had access to the internet.

\section{Qualitative}

The qualitative participants comprised 18 students (nine male and nine female) aged 15-20 years who reported that they had been victims and/or perpetrators of electronic aggression within 3 months of the study.

\section{Sample size estimation}

\section{Quantitative}

The sample size formula for cross-sectional studies, $\mathrm{n}=(\mathrm{P}$ $(100-\mathrm{P})) /(\mathrm{SE})^{2},{ }^{46}$ was used (this has been described in a previous publication). ${ }^{47} \mathrm{~A}$ total of 653 eligible students (318 males and 335 females) gave consent/assent and were interviewed.

\section{Qualitative}

We planned to interview 16-20 students as we anticipated that with this number we would attain saturation; 18 students were eventually interviewed.

\section{Sampling technique}

\section{Quantitative}

A multi-stage sampling technique was used to select the 653 students (also described in previous publications). ${ }^{46} 48$

Qualitative

The qualitative respondents were purposively selected.

\section{Study instruments}

Quantitative

Information was obtained from the students with the aid of a pre-tested interviewer-assisted electronic questionnaire (please see online supplementary file II for additional details). Questionnaires were completed electronically using laptop computers. We ran internal consistency tests on questions assessing victimisation and perpetration of electronic aggression and obtained Cronbach's $\alpha$ of 0.65 for the victimisation questions and 0.69 for the perpetration questions.

\section{Qualitative}

An in-depth interview guide was used to explore issues surrounding a history of cyberbullying perpetration or victimisation.

All instruments were translated and back-translated into Yoruba, the predominant language in the study area. Overall, approximately 30 students preferred to be interviewed using the Yoruba version of the instrument and these students attending schools located within the rural local government area.

\section{Data collection procedure}

\section{Ethical issues}

Ethical approval for the study was obtained from the University of Ibadan/University College Hospital, Ibadan, Ethical Review Board. Permission was also obtained from the State Ministry of Education and the Local Inspectorate of Education. The principals of each of the schools provided consent for the investigators to interview each student after going through a paper version of the questionnaire. Students who were 18 years or older also provided informed consent while those younger than 18 years provided assent. All respondents were assured that their responses would be kept confidential.

\section{Quantitative}

All students were taken through the process of informed consent/assent. It took about $15-25 \mathrm{~min}$ on average to complete the questionnaire and this was administered during the students' break or other free period specified by the school authorities. The school authorities provided a quiet room within the premises for administration of the instrument and the in-depth interviews. Each student was assisted by a member of the research staff who had been trained and had experience of conducting surveys on sensitive issues with adolescents. 
Qualitative

Two research staff (the interviewer and the note taker) conducted each in-depth interview and the interviews were digitally recorded.

Overall, the pretest and data collection lasted about 4 months.

\section{Measures}

Our independent variable was gender (male or female). The dependent variables were:

1. Experience of electronic aggression

A. Prevalence of electronic aggression (perpetration): This was assessed based on a self-reported history of aggression perpetrated via at least one media channel in the 3 -month period preceding the study.

B. Prevalence of electronic aggression (victimisation) in the 3-month period preceding the study.

2. Effects of the last incidence of electronic aggression on cyberbullies and cyber victims

3. Reporting of incidents of electronic aggression.

\section{Data analysis}

Quantitative data

The quantitative data were exported into SPSS V.20 and analysed with the same software. The association between gender and experience, effects and reporting of electronic aggression were examined using the $\chi^{2}$ test and Fisher's exact $\mathrm{p}$ value was reported as some of the cells had small expected counts. ${ }^{49}$ The level of significance was $\mathrm{p}<0.05$.

\section{Qualitative data}

Qualitative data were analysed using a constant comparative analysis approach ${ }^{50} 51$ and the process was led by the principal investigator (PI). All the in-depth interviews were transcribed verbatim and those conducted in the local language (Yoruba) were translated by an independent member of staff. The translated transcripts were then loaded onto ATLAS.ti software (Scientific Software, Berlin; V.7) and coded. Codes were later grouped into broader categories and themes that captured the content of each of these categories were developed and assigned to them. For each of the themes, we conducted a cross-case analysis to explore gender differences in the students' experience, effects and reporting of electronic aggression.

\section{RESULTS}

\section{Sociodemographic characteristics and internet use by gender}

The 653 quantitative respondents comprised 318 $(48.7 \%)$ male and $335(51.3 \%)$ female students with an overall mean age of $14.2 \pm 2.2$ years. The ages of the male $(14.2 \pm 2.2$ years $)$ and female $(14.2 \pm 2.1$ years $)$ students were comparable and about $80.0 \%$ were currently residing with both parents. A significantly higher proportion of males $(59.1 \%)$ than females $(42.4 \%)$ had access to the internet $\left(\chi^{2}=18.270 ; p<0.001\right)$. The male and female students often accessed the internet on a personal phone or on a computer at home. Frequency of internet use was significantly higher among male than female students: $51.9 \%$ of male students and $37.3 \%$ of female students used the internet every day to at least once a week $\left(\chi^{2}=21.369 ; \mathrm{p}<0.001\right)($ table 1$)$.

\section{Prevalence and association between gender and cyberbullying perpetration and victimisation}

There was no significant difference in the proportion of male $(25.8 \%)$ and female $(22.1 \%)$ students who perpetrated electronic aggression within 3 months of the study. A higher proportion of female $(42.7 \%)$ than male (36.8\%) students had been victims of electronic aggression, although this difference was not statistically significant. A higher proportion of male students were victim/ perpetrators $(22.6 \%)$ and perpetrators only $(3.1 \%)$, while more females $(23.3 \%)$ than males $(14.2 \%)$ were victims only $\left(\chi^{2}=8.999 ; \mathrm{p}<0.028\right)$ (table 2$)$.

\section{Students' experience of electronic aggression in the last 3 months}

Perpetrator's experience of electronic aggression by gender

A total of 156 students had perpetrated electronic aggression. The most common methods used by the male and female students were phone call, chatroom and text message. Generally, there were no significant differences in electronic media channels used by the male and female perpetrators of electronic aggression. Fifty-eight per cent of the females compared to $40.3 \%$ of males perpetrated electronic aggression via phone calls. However, more males than females perpetrated electronic aggression via chatrooms $(33.8 \%$ vs $22.6 \%)$ and text messages $(19.5 \%$ and $16.1 \%)$. More than $90.0 \%$ of the male and female perpetrators bullied their victims after school hours. About two-thirds of the male perpetrators $(65.8 \%)$ reported that their last victims were other males, while $52.5 \%$ of the female perpetrators had bullied other females $\left(\chi^{2}=4.509 ; p=0.037\right)$. Fifty-five per cent of male perpetrators and $43.8 \%$ of female perpetrators reported that their victims were in the same class as them; about a third each reported that their victims were in a different school from them.

Victims' experiences of electronic aggression by gender On the whole, there were no statistically significant gender differences in the victims' experiences of electronic aggression. Comparable proportions of male $(50.9 \%)$ and female $(55.1 \%)$ students were victimised via phone calls. Approximately $30 \%$ of males and $21.0 \%$ of females were harassed in a chatroom. Slightly more females $(21.7 \%)$ than males $(17.0 \%)$ were harassed via text message. The majority of incidents of electronic aggression (87.3\% among the males and $91.2 \%$ among the females) occurred outside school premises and more than $90 \%$ of incidents occurred after school 
Table 1 Sociodemographic characteristics and internet use by gender

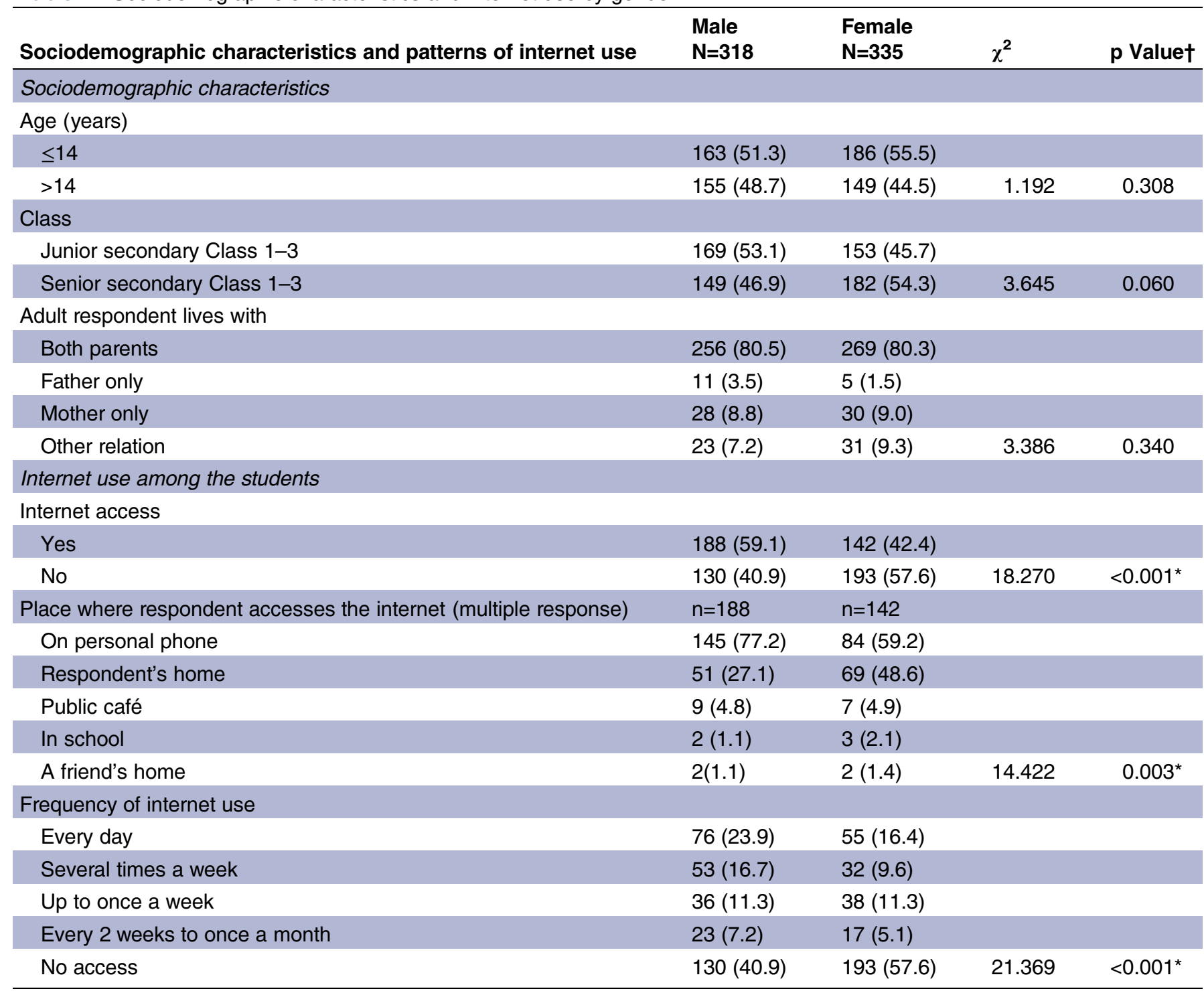

*Statistically significant.

†Fisher's exact $p$ value.

hours. Similar proportions of male and female victims (about three quarters) knew the person who bullied them quite well and $>60 \%$ of both males and females stated that they were bullied by a male. This was also similar to the accounts provided by the qualitative respondents. Approximately $14 \%$ of male victims and $9.9 \%$ of female victims were physically confronted by the bully after the incident of electronic aggression (table 2). The common types of electronic aggression both females and males experienced were mean/hurtful and abusive words. However, a higher proportion of females $(23.8 \%)$ than males $(3.7 \%)$ were victims of unwanted solicitation for dating relationships and sexual advances (5.9\% females and none of the males) (table 3 ).

Generally, the experiences of the in-depth interviewees corroborated those of the quantitative respondents. The female in-depth interviewees stated that electronic aggression most often occurred via text message followed by phone calls and in chatrooms. For males, bullying was often experienced via phone calls, in chatrooms and also text messaging. The types of electronic aggression messages experienced by female participants were often mean words, repeated teasing and sexting. Solicitations for dating relationships or sex were reported by more females than males. These unwanted solicitations were sometimes followed by threats or mean words/abusive exchanges when they turned down these requests (table 4: example1). A female in-depth interviewee was a victim of an embarrassing Facebook post by an unknown person (table 4: example 2). Common types of electronic aggression behaviour experienced by the male in-depth interviewees were threats, repeated extortion for money and occasionally sexting (table 4: example 3). More female than male in-depth interviewees reported that unsolicited sexually explicit pictures were sent to them. A few females stated that when they 
Table 2 Students' experience of electronic aggression in the last 3 months by gender

\begin{tabular}{|c|c|c|c|c|}
\hline Students' experience of electronic aggression in the last 3 months & Male & Female & $\chi^{2}$ & p Valuef \\
\hline \multicolumn{5}{|l|}{ Perpetrator } \\
\hline No & $236(74.2)$ & $261(77.9)$ & & 0.272 \\
\hline \multicolumn{5}{|l|}{ Victim } \\
\hline No & $201(63.2)$ & $192(57.3)$ & & 0.129 \\
\hline \multicolumn{5}{|l|}{ Both victim and perpetrator } \\
\hline Victim and perpetrator & $72(22.6)$ & $65(19.4)$ & & \\
\hline Victim only & $45(14.2)$ & $78(23.3)$ & & \\
\hline Perpetrator only & $10(3.1)$ & $9(2.7)$ & & \\
\hline Phone call & $31(40.3)$ & $36(58.1)$ & & \\
\hline Chatroom & $26(33.8)$ & $14(22.6)$ & & \\
\hline Text message & $15(19.5)$ & $10(16.1)$ & & \\
\hline Website & $2(2.6)$ & $1(1.6)$ & & \\
\hline Picture/online video clip & $2(2.6)$ & $1(1.6)$ & & \\
\hline Email & $1(1.3)$ & 0 & 5.080 & 0.389 \\
\hline Time when bully harassed his/her victim & $\mathrm{n}=75$ & $n=62$ & & \\
\hline During school hours & $3(4.0)$ & $6(9.7)$ & & \\
\hline After school hours & $72(96.0)$ & $56(90.3)$ & 1.782 & 0.299 \\
\hline Same class but different arm & $10(14.9)$ & $6(10.5)$ & & \\
\hline Senior class & $3(4.5)$ & $6(10.5)$ & & \\
\hline Lower class & $2(3.0)$ & $2(3.5)$ & & \\
\hline Different class & $2(3.0)$ & $5(8.8)$ & & \\
\hline Different school & $23(34.3)$ & $19(33.3)$ & 4.279 & 0.520 \\
\hline Media channel & $\mathrm{n}=112$ & $n=138$ & & \\
\hline Phone call & $57(50.9)$ & $76(55.1)$ & & \\
\hline Chatroom & $34(30.4)$ & $29(21.0)$ & & \\
\hline Text message & $19(17.0)$ & $30(21.7)$ & & \\
\hline Website & 0 & $1(0.7)$ & & \\
\hline Email & $1(0.9)$ & $1(0.7)$ & & \\
\hline Picture/online video clip & $1(0.9)$ & $1(0.7)$ & 3.919 & 0.513 \\
\hline Place where victim experienced harassment $n=110$ & & $\mathrm{n}=137$ & & \\
\hline In school & $14(12.7)$ & $12(8.8)$ & & \\
\hline Out of school & $96(87.3)$ & $125(91.2)$ & 1.020 & 0.405 \\
\hline Time when victim experienced harassment & $n=110$ & $n=137$ & & \\
\hline During school hours & $9(8.2)$ & $5(3.6)$ & & \\
\hline After school hours & $101(91.8)$ & $132(96.4)$ & 2.344 & 0.167 \\
\hline
\end{tabular}


Table 2 Continued

\begin{tabular}{|c|c|c|c|c|}
\hline Students' experience of electronic aggression in the last 3 months & Male & Female & $\chi^{2}$ & p Valuet \\
\hline Is harasser well known to victim? & $n=112$ & $n=137$ & & \\
\hline Yes & $83(74.1)$ & $101(73.7)$ & & \\
\hline Gender of the person who harassed victim $n=105$ & & $n=125$ & & \\
\hline Male & $65(61.9)$ & $83(66.4)$ & & \\
\hline Both male and female & $9(8.6)$ & $6(4.8)$ & 1.434 & 0.487 \\
\hline Perpetrator's class & $n=102$ & $n=130$ & & \\
\hline Same class & $30(29.4)$ & $32(24.6)$ & & \\
\hline Same class but different arm & $6(5.9)$ & $7(5.4)$ & & \\
\hline Higher class & $4(3.9)$ & $11(8.5)$ & & \\
\hline Don't know perpetrator & $12(11.8)$ & $20(15.4)$ & 7.221 & 0.326 \\
\hline Confronted by perpetrator & $n=101$ & $n=131$ & & \\
\hline Yes & 14 (13.9) & $13(9.9)$ & & \\
\hline No & 87 (86.1) & $118(90.1)$ & 0.860 & 0.411 \\
\hline
\end{tabular}

*Statistically significant.

†Fisher's exact $p$ value.

received these pictures, their response was to send similar sexually explicit pictures to the males who had initially sent the pictures to them (table 4: example 4).

A 15-year-old male student had been a victim of bullying (electronic and traditional) for about 2 months before he eventually reported it to a teacher. He explained that he borrowed some money from a friend and the bully overheard their conversation and later stalked him and said the friend asked him to collect the money. The victim received repeated text messages and phone calls from the bully with messages such as, "If you don't bring my money to class now, I will beat you beyond recognition". He further said, "....most times he calls me, he just insults me that if I don't come with the money he will beat hell out of me and stuff like that". The victim later found out that the friend who lent him the money had not asked the bully to demand the money on his behalf.

\section{Gender differences in effect and reporting of electronic aggression by perpetrators and victims}

Sixty-four male and 60 female perpetrators provided information on the effect the last incident of electronic aggression they perpetrated had on them. There was no significant difference in the effects of electronic aggression on the male and female perpetrators. A third of female perpetrators compared with $17.2 \%$ of male perpetrators felt very sad, while $16.8 \%$ of females and $14.1 \%$ of males felt angry (table 3). Similarly, there was no significant difference in the effect of the last incident of electronic aggression on the male and female victims.
About $45 \%$ each felt very sad while slightly more males (45.4\%) than females (39.4\%) reported that they felt very angry. A few males and females felt afraid $(2.8 \%$ and $3.6 \%)$ and became withdrawn $(0.9 \%$ and $4.4 \%)$.

The in-depth interview reports supported the quantitative findings as both male and female interviewees reported that they felt very sad, unhappy and angry and a few had a headache after the incidents. Some students said they simply ignored the perpetrator or blocked them from their social media or chat room or blocked their calls. The male in-depth interviewee who was a victim of traditional and electronic aggression said the incident made him feel, 'bad, scared and down'. He explained, "

At times I would feel so bad, scared...down. Many times I even pretended as if I was sick and I would not come to school."

When his parents took him to hospital, he made up stories to try to convince doctors that he was ill (table 4: example 5).

\section{Gender differences in reporting of incidents of electronic} aggression

A higher proportion of female $(59.1 \%)$ than male $(42.7 \%)$ victims reported the last incident of electronic aggression they encountered to someone $\left(\chi^{2}=6.698\right.$; $\mathrm{p}=0.035$ ). About $60 \%$ of males compared to $46.9 \%$ of females informed a friend, and similar proportions of males and females informed a parent or guardian. However, $17.3 \%$ of females compared to $6.3 \%$ of males informed another relative such as an aunt, uncle or 
BMJ Global Health

Table 3 Type of message, effect and reporting of electronic aggression by perpetrator and victim

\begin{tabular}{|c|c|c|c|c|}
\hline Effect and reporting by perpetrator and victim & Male & Female & $\chi^{2}$ & p Valuet \\
\hline \multicolumn{5}{|l|}{ Perpetrator } \\
\hline Type of harassment message sent by perpetrator & $\mathrm{n}=51$ & $\mathrm{n}=37$ & & \\
\hline Mean or hurtful things & $10(19.6)$ & $13(35.1)$ & & \\
\hline Ignore/exclude & $0(0)$ & $1(2.7)$ & & \\
\hline Threats & $2(3.9)$ & $2(5.4)$ & & \\
\hline Sharing secrets or embarrassing information & $2(3.9)$ & $0(0.0)$ & & \\
\hline Impersonation & $1(2.0)$ & $0(0.0)$ & & \\
\hline Others & $2(3.9)$ & $2(5.4)$ & 7.113 & 0.422 \\
\hline Effect of incident on perpetrator & $n=64$ & $n=60$ & & \\
\hline Started keeping to myself & $1(1.6)$ & $2(3.3)$ & & \\
\hline Felt afraid & $1(1.6)$ & $2(3.3)$ & 6.975 & 0.1004 \\
\hline \multicolumn{5}{|l|}{ Victim } \\
\hline Types of messages received by victim & $\mathrm{n}=82$ & $n=101$ & & \\
\hline Mean or hurtful things/make fun of & $34(41.5)$ & $38(37.6)$ & & \\
\hline Abusive words & $34(41.5)$ & $20(19.8)$ & & \\
\hline Ignore/exclude & $1(1.2)$ & $0(0)$ & & \\
\hline Tell lies/spread rumours & $0(0)$ & $2(2.0)$ & & \\
\hline Relationship advances & $3(3.7)$ & $24(23.8)$ & & \\
\hline Effect of incident on victim & $n=108$ & $n=137$ & & \\
\hline No effect & $18(16.7)$ & $22(16.1)$ & & \\
\hline Felt very sad & $50(46.3)$ & $62(45.3)$ & & \\
\hline Felt angry & $49(45.4)$ & $54(39.4)$ & & \\
\hline Felt afraid & $3(2.8)$ & $5(3.6)$ & & \\
\hline Started keeping to him/herself & $1(0.9)$ & $6(4.4)$ & & \\
\hline Didn't feel like going to school & $1(0.9)$ & $2(1.5)$ & & \\
\hline Developed headache & 0 & $5(3.6)$ & & \\
\hline Others $\ddagger$ & $6(5.6)$ & $13(9.5)$ & 8.413 & 0.3103 \\
\hline \multicolumn{5}{|l|}{ Victims immediate response $(n=247)$} \\
\hline Nothing & $49(44.5)$ & $42(30.7)$ & & \\
\hline Informed someone & $47(42.7)$ & $81(59.1)$ & & \\
\hline Other§ & $14(12.7)$ & $14(10.2)$ & 6.698 & $0.035^{\star}$ \\
\hline Who did victim inform? & $\mathrm{n}=48$ & $\mathrm{n}=81$ & & \\
\hline Friend & $29(60.4)$ & $38(46.9)$ & & \\
\hline Parent/guardian & $14(29.2)$ & $23(28.4)$ & & \\
\hline A relative & $3(6.3)$ & $14(17.3)$ & & \\
\hline Teacher & $1(2.1)$ & $1(1.2)$ & & \\
\hline
\end{tabular}


Table 3 Continued

\begin{tabular}{lllll}
\hline Effect and reporting by perpetrator and victim & Male & Female & $\chi^{2}$ & p Valuet \\
\hline Another adult & $0(0)$ & $3(3.7)$ & & 0.301 \\
Others & $1(2.1)$ & $2(2.5)$ & 5.786 & \\
Reasons for choice of informant & $\mathrm{n}=47$ & $\mathrm{n}=83$ & & \\
Close to victim & $23(48.9)$ & $49(59.0)$ & & \\
The person can handle the problem & $7(14.9)$ & $6(7.2)$ & & \\
A friend to bully & $3(6.4)$ & $4(4.8)$ & & \\
Need advice & 0 & $8(9.6)$ & & $0.036^{*}$ \\
Aware of preceding events & $3(6.4)$ & $1(1.2)$ & 12.653 & \\
Was angry & 0 & $3(3.6)$ & & \\
Others** & $11(23.4)$ & $12(14.5)$ & & \\
\hline
\end{tabular}

*Statistically significant.

tFishers exact $p$ value.

‡Others included felt bad, embarrassed, cried.

§Others included called back to harass the person, blocked the person on social media, harassed the person back, sent the same message

back to cyberbully, started crying.

ПOthers such as the perpetrator's friend.

${ }^{* *}$ Others included just want him to know, the person is mature.

older sibling. The most common reason for the choice of the person the victim reported to was that this person was close to the victim $(48.9 \%$ males and $59.0 \%$ females) and this was someone the victim felt could intervene $(14.9 \%$ and $7.2 \%$, respectively). This pattern was similar to the in-depth interviewees' responses as more females than males reported the incident to someone close to them and who they felt was in a position to put an end to the harassment, such as a parent, teacher, aunt or friend. Males often informed their friends. The male victim who endured electronic aggression for about 2 months before he eventually reported the incident explained that he did not report the incident to anyone at the onset because other victims who had reported such incidents in the past had not obtained any respite (table 4: example 6). He eventually summoned up courage and reported the electronic aggression to his teacher and parents who stepped in and the bullying eventually stopped.

On the whole, the students were of the opinion that the newer electronic media were very beneficial and that although harassment and bullying via these technologies could not be eliminated, steps need to be taken to protect students from the negative effects associated with these media.

\section{DISCUSSION}

This study, which was conducted to explore gender differences in the prevalence, effects and reporting of electronic aggression among students in Oyo state, revealed varied gender differences in the study outcomes.

\section{Internet use among students by gender}

First, significant gender differences in access and frequency of utilisation of the internet were found and more males than females males had access to and used the internet frequently. This is similar to the findings of reports from other studies. ${ }^{5852}$ A possible explanation for better access and utilisation of the internet among males than females could be that internet use in the majority of government-owned schools in the study area and indeed in the country is not yet widespread. ${ }^{53}$ Hence students who do not have access to computers and the internet in school and at home often utilise cybercafés within their neighbourhoods. While there is no gender restriction with respect to accessing these cybercafés, anecdotal reports suggest that the operation of many of these cybercafés could in some way limit use by females. This is because many cybercafés have both day and all night browsing services, and the all night browsing services are often cheaper and faster than day-time services. However, students (male and female) are engaged in school for the greater part of the day and often attend additional lessons after school, thus reducing the daytime hours for accessing the cybercafés. While males can thus take advantage of the late evening and all night browsing services, most females are unable to do this because they are often not permitted by their parents to move around the neighbourhood at night because of general concerns for their safety. This is in line with existing gender socialisation theories that propose that boys and girls are socialised differently and this often results in reduced mobility for girls. These gender restrictions thus reduce opportunities to utilise the internet and become proficient in its use among females.

\section{Gender and prevalence of electronic aggression among students}

In the current study, there were no significant gender differences in the perpetration or victimisation of electronic aggression. This is similar to findings of a number 
Table 4 Additional explanatory quotes from in-depth interviewees

\section{Quotes}

Type of electronic aggression behaviour

Example 1: flaming: Use of mean, hurtful/ abusive words

\section{Example 2: Embarrassing post}

Example 3: Threats

Example 4: Repeated sexting

Example 5: Effect of electronic aggression on a victim
"I met the guy on 2-go chatting together so he just came one day to our house and told me that he needed to see me without informing me that he was coming to see me. When I saw him, I did not even behave as if I knew him so then he left. The next day we met on 2-go again and he said he will soon send something to me ... and he sent the message and it reads, I am an adult that I don't have respect at all, and that I did not behave as if I know him when he came to our house. He even said that maybe my parents did not train me well that's why I don't have respect for people ... ... "that I am a harlot". I harassed him back and told him that maybe he is following his father's footstep that's why he is behaving like that". 19-year-old female cyberbully victim and perpetrator

Respondent: ... I don't know the person ... he now commented on my wall on Facebook. I didn't reply...he sent me a text message and I still didn't reply. The next thing he would say, is “ 'Asewo'[meaning commercial sex worker] can't reply because you have "business" on Facebook'. Many people commented on this.... but I didn't know the person that wrote that initial comment on Facebook. The person did not use his real picture.... he put a box on his profile picture and his name also. The person embarrassed me but I don't know who he was. I investigated but people didn't know the person.18-year-old female cyberbully victim and perpetrator

Interviewer: Have you ever been harassed in the past 3 months?Respondent: Yes. Interviewer: By who?Respondent: I don't know him, he just called me on phone; I was surprised how he got my number.Interviewer: What made you to think that you were harassed?Respondent: He threatened me on phone.Interviewer: Then how did you feel the moment you heard it?Respondent: I was afraid, scared, I was restless, thinking, "What am I going to do to stop this?"Interviewer: Did you take any action? Respondent: I told my close friend and he advised me that I should be patient, I should inform him about anything that happens afterwards. Interviewer: Why didn't you inform your parents?Respondent: Because the voice I heard on phone was not a grown up's voice. The voice sounded like somebody of my age. That was why I did not inform my parents and decided to share it with my very close friend. Also if anything happen to him [my close friend], I will be the first person he will inform. Interviewer: Did you still continue dating the girl or you ended the relationship? Respondent: I later stopped dating the girl...... and the moment I did this, I have not received any harassing call or text message from anybody.15-year-old male victim of electronic aggression

Interviewer: ... In school again you harassed someone through picture?Respondent: I sent him (a male friend) a "rubbish picture"Interviewer: What was in the picture? Respondent: It was a "female breast" that I sent to himlnterviewer: What were your reasons for sending that to him?Respondent: Because he has done such thing to me before, so I revenged by sending it back to himInterviewer: What kind of picture did he send to you?Respondent: He sent me a male picture .... naked picture of a male's private partlnterviewer: What did he do after you sent him that picture?Respondent: He got angry and told me what is the meaning of the picture I sent to him and I replied that he had already send something like that to me before that it was reason why I revenged. I went to beg him and apologised. 19-year-old female victim and perpetrator

Interviewer: What effect did the incident have on you?Respondent: At times I would feel so bad, scared ... down. Many times I even pretended as if I was sick and I would not come to school. Interviewer: About how many times did you pretend as if you are sick?Respondent: Like five to seven times.Interviewer: ... and your parents never bother to take you for test (medical test)?Respondent: They took me, I made up stories to convince the doctors, but they (the doctors) carried out some tests but I was okay ....... And doctors thought it was academic stress. They just said I needed to rest. 15-year-old male victim

Example 6: Reason for delay in reporting of electronic aggression
"They [other students] gave examples, of people that reported in the past, and their parents did not do anything. Like there was an incident, whereby a parent brought the police to the school and nothing happened... He [the bully] told me that if I dare report to my parents that will be my last day on earth. 15-year-old male victim 
of researchers who have reported no significant gender differences in perpetration and victimisation of electronic aggression ${ }^{811} 2954$ among their respondents. It is possible that the significantly higher internet access of the males compared to the females could have moderated the association between gender and electronic aggression in the present study.

\section{Gender differences in students' experiences of electronic aggression}

There were no significant differences in channels used for perpetration and victimisation; however, more male than female students perpetrated electronic aggression via chatrooms (33.8\% of males and $22.6 \%$ females), while more females $(58.1 \%)$ than males $(40.3 \%)$ perpetrated electronic aggression via phone calls. This finding could also be a reflection of the higher frequency of internet use by our male than female respondents. Both male and female victims and perpetrators reported that electronic aggression occurred more after school hours than during school. This reiterates reports from other studies on electronic aggression among secondary school students. ${ }^{27}$ This finding could be because the use of cellphones in most secondary schools in the study area is not permitted. However, this emphasises the added problem posed by electronic aggression which is that, unlike traditional aggressive behaviours including bullying, the perpetrator of electronic aggression can strike at any time regardless of whether he/she is physically close to his victim or not.

Our results on the gender differences in types of electronic aggression behaviours experienced by male and female perpetrators and victims were generally varied (although not statistically significant). More females than males were victims of unwanted dating and sexual advances, which often resulted in threats or mean and hurtful exchanges or use of abusive words when the females refused these advances. This finding was also echoed by our in-depth interviewees. Mishna et $a \tilde{l}^{5}$ also reported that although sexual harassment was a common form of peer victimisation for both boys and girls, it was more of a problem among girls. ${ }^{55}$ More of our female respondents also reported that sexually-explicit pictures were sent to them. The preponderance of unwanted dating advances experienced by females in our study area could also be influenced by the traditional gender notions still prevalent in Nigeria and many other societies -that men are expected to initiate requests for dating relationships. Hence the likelihood of males reporting incidents of being asked for relationships by femaleswhether wanted or otherwise, face-to-face or in cyberspace —would be low.

\section{Gender differences in the effects of electronic aggression on perpetrators and victims}

In the current study, there was no significant difference in the effects of electronic aggression among male and female perpetrators and victims, although a higher proportion of male $(65.5 \%)$ than female $(43.3 \%)$ perpetrators stated that the incident had no effect on them. This difference (though not statistically significant) could be because society generally expects males to be 'aggressive' whereas females are expected to be 'mild mannered'. Hence, females who had taken on the 'aggressive' role of bullying another person may have experienced some 'conflict' which would result in their being bothered when they cyberbullied someone else. Similar proportions of males and females (about 16\% each) said the incident had no effect on them and similar proportions felt sad, although more males (45.4\%) than females (39.4\%) felt angry afterwards. When viewed against existing gender socialisation theories and norms which portray men as strong and invincible and women as caring and 'passive', one would actually expect that a lower proportion of male than female victims of electronic aggression would have stated that the incident had an effect on them. Some possible reasons may be that, in some instances, the incidents are perceived by the victim as being mild and as such the victim simply ignores these. Also, some victims might not perceive the incidents as being malicious enough to be taken seriously. Literature on the effects of electronic aggression on male and female victims has also reported a wide range of findings. For example, similar to our findings, Beran and $\mathrm{Li}^{32}$ found no gender differences in the effect of electronic aggression on their victims. Ortega $e t$ al ${ }^{56}$ however, demonstrated that more male than female victims were not bothered by incidents of electronic aggression they had experienced.

\section{Gender differences in reporting of electronic aggression by victims}

We found a statistically significant difference in the immediate response of victims to incidents of electronic aggression. Males were significantly less likely to inform someone of the incident (43\%) than females $(59 \%)$. This finding might reflect the general societal expectations in Nigeria and indeed many African countries, where men are expected to suppress their hurt and not reveal that they are distressed as a sign of their 'masculinity'. ${ }^{19}$ This situation often continues and manifests as a reluctance to seek healthcare among men when they are ill later in life. A study among students in Austria and Australia similarly reported that girls in both countries were significantly more likely to seek help than boys. ${ }^{34}$

There were some differences in the person to whom the last incident of electronic aggression was reported. More males than females informed a friend and more females informed an older relative than males. Common reasons for the choice of the person that the incident was reported to among both male and female respondents was that this was someone close to them, followed by someone they felt could help them. This choice might be reflective of the developmental stage of adolescence in which individuals form tight relationships with 
their peers and reach out to them more than parents when they are bothered by issues. Our findings are similar to reports by Holfeld and Grabe ${ }^{26}$ in which many victims who reported the incident often informed their peers followed by parents/guardians then siblings and teachers. Other reasons why victims could be reluctant to inform parents or older adults could be because they did not perceive that these adults could put an end to the problem. This has been echoed by other studies and indeed by one of our qualitative participants. Mishna et $a e^{57}$ found that some victims were reluctant to inform their teachers that they were being cyberbullied because they did not think they could help since cyberbullying often occurred off school grounds. Findings from this study also support this notion as one of our in-depth interviewees mentioned that he did not report the cyberbullying to anyone because he felt they could not help, as other students who had experienced similar incidents and had reported them said the incidents did not stop after reporting. Furthermore, some authors have also stated that some adolescents do not inform their parents because of the fear that they would take their phones or stop them from using the internet.

\section{CONCLUSION}

This study on the gender differences in electronic aggression among secondary school students in Oyo state, Nigeria found a high prevalence of electronic aggression among both male and female students. Overall, we did not find significant differences in perpetration, victimisation and effects of electronic aggression among the male and female students. We did, however, find that female victims were more likely to report the last incident of electronic aggression compared to male victims. In view of our findings, we recommend the following:

1. Interventions to increase awareness among students, teachers and parents should be instituted as an important step towards kerbing the problem.

2. Victims, especially the males, should be encouraged to report any incidents they suffer so they can receive timely and appropriate help. Parents, teachers and school authorities thus need to be provided with comprehensive information and skills to enable them to give prompt and appropriate assistance to victims of electronic aggression. This will instil confidence in victims that the issue will be effectively addressed when they report incidents.

3. It is important to train teachers, parents and adolescent health workers to recognise signs which could indicate that a student is experiencing electronic aggression to enhance early detection and prompt institution of relevant interventions.

Adolescent health workers also need to be made aware of the problem and to specifically enquire about a history of electronic aggression when managing adolescents. The existing acronym that guides assessment of adolescents in healthcare settings-HEEADSSS (Home environment, Education and employment, Eating, peerrelated Activities, Drugs, Sexuality, Suicide/depression, and Safety from injury ${ }^{58}$ is a useful tool for ensuring that opportunities to ask about and detect electronic aggression if it is occurring are not missed.

\section{Limitations}

One of the limitations of our study was that we relied on self-reported history of electronic aggression. Another limitation was that we provided a definition of cyberbullying to participants which might have resulted in some degree of under reporting by perpetrators since electronic aggression is not a socially desirable behaviour. We made efforts to overcome these limitations by emphasising the importance of answering questions honestly to all participants, reassuring them of confidentiality and that their responses would not be traced back to them.

In spite of these limitations, our findings contribute meaningfully to the existing literature on electronic aggression, globally and especially in developing countries where data are sparse. Our use of a mixed methods approach is a major strength of the study since we were able to harness the strengths of both methods. The qualitative aspect also provided rich in-depth experiences of the context in which electronic aggression occurred among the male and female students. Importantly, we demonstrate that there are some gender differences in the experience and reporting of electronic aggression which need to be taken into consideration when developing interventions to address the problem. We also recommend that additional studies on electronic aggression be conducted in developing countries which are experiencing rapid increases in mobile technology used by adolescents and young people.

Handling editor Soumitra Bhuyan

Twitter Follow Emmanuel Adebayo at @EmmyAdebayo

Acknowledgements The authors acknowledge Dr Eme T Owoaje, Director Research Management Office, University of Ibadan, Nigeria, Dr Akinnola Fatiregun for assistance with advanced statistical procedures, Patricia Adams (the Project Manager) and all the research staff, the school authorities and the study participants.

Contributors A00 was the principal investigator, conceptualised the study and was involved in data collection, data analysis and interpretation and drafting of the manuscript; EA was involved in analysis and writing up of the data for this paper; BO was involved in the fieldwork as a site supervisor, analysis and writing up of the qualitative findings and preparation of the current manuscript. All authors read and approved the final manuscript.

Funding Data for this paper was from research supported by the University of Ibadan, Senate Research Grant (No.: SRG/FCS/2010/5A).

Competing interests None declared.

Participant consent Obtained.

Ethics approval University of Ibadan/University College Hospital, Ibadan, Ethical Review Board.

Provenance and peer review Not commissioned; externally peer reviewed. 
Data sharing statement No additional data are available.

Open Access This is an Open Access article distributed in accordance with the Creative Commons Attribution Non Commercial (CC BY-NC 4.0) license, which permits others to distribute, remix, adapt, build upon this work noncommercially, and license their derivative works on different terms, provided the original work is properly cited and the use is non-commercial. See: http:// creativecommons.org/licenses/by-nc/4.0/

\section{REFERENCES}

1. Fox K. Africa's mobile economic revolution. Secondary Africa's mobile economic revolution 24 July, 2011. 2011. http://www. theguardian.com/technology/2011/jul/24/mobile-phones-africamicrofinance-farming

2. Lenhar A, Madden M. Social networking websites and teens: an overview. Washington DC: Pew internet and American life Project, 2007.

3. Lenhar A, Madden M, Smith A, et al. Teens and social media: the use of social media gains a greater foothold in teen life as they embrace the conversational nature of interactive online media. Washington DC: Pew internet and American life Project, 2007.

4. ITU/UNCTAD. World Information Society 2007 Report: Beyond WSIS. 2007. http://www.itu.int/osg/spu/publications/ worldinformationsociety/2007/ (accessed 19 May 2014).

5. Rideout VJ, Foehr UG, Roberts DF. Generation M2: media in the lives of 8- to 18-year-olds a Kaiser Family Foundation Study. Menlo Park, CA: Henry J. Kaiser Family Foundation, 2010:85.

6. David-Ferdon C, Hertz MF. Electronic media and youth violence: a CDC issue brief for researchers. 2009. http://www.cdc.gov/ violenceprevention/pdf/electronic_aggression_researcher_brief-a.pdf (accessed 5 Jul 2016).

7. Dooley JJ, Py zalski J, Cross D. Cyberbullying versus face-to-face bullying: a theoretical and conceptual review. J Psychol 2009;217:182-8.

8. Kowalski RM, Limber SP. Electronic bullying among middle school students. J Adolesc Health 2007;41(Suppl 1):S22-30.

9. Novo F, Pereira F, Matos M. Cyber-aggression among Portuguese adolescents: a study on perpetration, victim offender overlap and parental supervision. Int J Cyber Criminol 2014;8:94.

10. Sangowawa AO, Adebiyi AO. Electronic-media harassment among secondary school adolescents in Ibadan municipality Nigeria: myth or reality? Inj Prev 2010;16(Suppl 1):A253-4.

11. Ybarra ML, Mitchell JK. Online aggressor/targets, aggressors and targets: a comparison of associated youth characteristics. J Child Psychol Psychiatry 2004;45:1308-16.

12. Ybarra M, Mitchell $K$. Youth engaging in online harassment: associations with caregiver-child relationships, Internet use, and personal characteristics. J Adolesc 2004;27:319-36.

13. Burnette MM. Gender, gender identity and sexuality. In: McAnulty RD, Burnette MM, eds. Sex and sexuality. Sexuality today: trends and controversies. Westport, CT: Praeger, 2006:185-201.

14. Fatusi AO, Hindin MJ. Adolescents and youth in developing countries: health and development issues in context. $J$ Adolesc 2010;33:499-508.

15. Mmari KN, Oseni O, Fatusi AO. STI treatment-seeking behaviors among youth in Nigeria: are there gender differences? Int Perspect Sex Reprod Health 2010;36:72-9.

16. Olajubu O. Women in the Yoruba Religious Sphere. State University of New York Press, 2012.

17. Izugbara $\mathrm{CO}$. The socio-cultural context of adolescents' notions of sex and sexuality in rural south-eastern Nigeria. Sexualities 2005;8:600-17.

18. Macintyre S, Hunt K, Sweeting H. Gender differences in health: are things really as simple as they seem? Soc Sci Med 1996;42:617-24.

19. Courtenay WH. Constructions of masculinity and their influence on men's well-being: a theory of gender and health. Soc Sci Med 2000;50:1385-401.

20. Rolleri LA. Understanding Gender and Gender Equality [Internet]. Research fACTS and findings. 2013. http://www.actforyouth.net/ resources/rf/rf gender1_1213.cfm (accessed 9 Oct 2016).

21. Rolleri LA. Gender norms and sexual health behaviors [Internet]. Research fACTS and findings. 2013. http://www.actforyouth.net/ resources/rf/rf gender2 1213.pdf (accessed 9 Oct 2016).

22. Smith PK, Cowie H, Olafsson RF, et al. Definitions of bullying: a comparison of terms used, and age and gender differences, in a fourteen-country international comparison. Child Dev 2002;73:1119-33.
23. Björkqvist K, Lagerspetz KM, Kaukiainen A. Do girls manipulate and boys fight? Developmental trends in regard to direct and indirect aggression. Aggress Behav 1992;18:117-27.

24. Crick NR, Bigbee MA. Relational and overt forms of peer victimization: a multiinformant approach. J Consult Clin Psychol 1998;66:337.

25. Wang J, lannotti RJ, Nansel TR. School bullying among adolescents in the United States: physical, verbal, relational, and cyber. $J$ Adolesc Health 2009;45:368-75.

26. Holfeld B, Grabe M. An examination of the history, prevalence, characteristics, and reporting of cyberbullying in the United States. Malden, MA: Blackwell Publishers Ltd, 2012.

27. Smith PK, Mahdavi J, Carvalho M, et al. Cyberbullying: its nature and impact in secondary school pupils. J Child Psychol Psychiatry 2008;49:376-85.

28. Navarro R. Gender issues and cyberbullying in children and adolescents: from gender differences to gender identity measures. Cyberbullying Across the Globe: Springer, 2016:35-61.

29. Williams KR, Guerra NG. Prevalence and predictors of internet bullying. J Adolesc Health 2007;41(6 Suppl):S14-21.

30. Barlett C, Coyne SM. A meta-analysis of sex differences in cyber-bullying behavior: the moderating role of age. Aggress Behav 2014:40:474-88.

31. Huffman $\mathrm{AH}$, Whetten J, Huffman $\mathrm{WH}$. Using technology in higher education: the influence of gender roles on technology self-efficacy. Comput Hum Behav 2013;29:1779-86.

32. Beran T, Li Q. Cyber-harassment: a study of a new method for an old behavior. J Educ Comput Res 2005;32:265-77.

33. Ybarra ML. Linkages between depressive symptomatology and internet harassment among young regular internet users. Cyberpsychol Behav 2004;7:247-57.

34. Dooley JJ, Gradinger P, Strohmeier D, et al. Cyber-victimisation: the association between help-seeking behaviours and self-reported emotional symptoms in Australia and Austria. Aust $J$ Guidance Couns 2010;20:194-209.

35. Oyewusi LM, Orolade KS. "Cyberbullying": a disruptive behaviour in modern day secondary school classrooms. J Educ Soc Res 2014;4:421.

36. Burton P, Mutongwizo T. Inescapable violence: cyber bullying and electronic violence against young people in South Africa. Centre Justice Crime Prev 2009;8:1-12.

37. Christine B, Bhat $\mathrm{S}$, Chang $\mathrm{S}$, et al. Cyberbullying in Asia. Educ ABOUT ASIA 2013;18:36-9.

38. Kunnuji MON. Adolescence, young adulthood and internet use in Nigeria: a review of what is known and unknown. Int $J$ Econ Manag Soc Sci 2014;3:11-17.

39. Pew Research Center. Cell phones in Africa: communication lifeline. Pew Research Centre, 2015:16.

40. Internet World Statistics (IWS). Nigeria: Internet Usage and Telecommunications Reports. Secondary Nigeria: Internet Usage and Telecommunications Reports 5 July 2016. 2015. http://www. internetworldstats.com/africa.htm\#ng

41. Friedman AL, Brookmeyer KA, Kachur RE, et al. An assessment of the GYT: Get Yourself Tested campaign: an integrated approach to sexually transmitted disease prevention communication. Sex Transm Dis 2014:41:151-7.

42. Kachur R, Mesnick J, Liddon N, et al. Adolescents, technology and reducing risk for HIV, STDs and pregnancy. Atlanta, GA: Centers for Disease Control and Prevention, 2013.

43. National Institutes of Health. Qualitative methods in health research: opportunities and considerations in application and review. Washington DC, USA: National Institutes of Health (Office of Behavioral and Social Sciences Research), 2001.

44. Cresswell JW. Designing and conducting mixed methods research. 2nd edn. California, USA: Sage Publications, Inc., 2001.

45. The official website of Oyo state. The pacesetter state. Secondary The pacesetter state 2014. 2014. http://www.oyostate.gov.ng/

46. Fox N, Hunn A, Mathers N. Sampling and sample size calculation. East Midlands/Yorkshire: the National Institutes for Health Research. Research Design Service for the East Midlands/Yorkshire \& the Humber, 2009.

47. Olumide AO, Adams P, Amodu OK. Prevalence and correlates of the perpetration of cyberbullying among in-school adolescents in Oyo State, Nigeria. Int J Adolesc Med Health 2016;28:183-91.

48. Olumide AO, Adams P, Amodu OK. International Note: awareness and context of cyber-harassment among secondary school students in Oyo state, Nigeria. J Adolesc 2015;39:10-14.

49. McDonald JH. Handbook of biological statistics. Baltimore, MD: Sparky House Publishing, 2009.

50. Glaser B, Strauss A. The discovery of grounded theory: strategies for qualitative research. Chicago: Aldin Pub: Co, 1967. 
51. Leech NL, Onwuegbuzie AJ. Qualitative data analysis: a compendium of techniques and a framework for selection for school psychology research and beyond. Sch Psychol Q 2008;23:587.

52. Olumide AO, Ojengbede OA. The media as a critical determinant of the sexual and reproductive health of adolescents in Ibadan, Nigeria. Sex Reprod Healthc 2016;8:63-74.

53. Olatokun WM. Internet access and usage by secondary schoo students in a Nigerian Municipality. South African J Libr Inf [Internet] 2008;74:138-48.

54. Walrave M, Heirman W. Cyberbullying: predicting victimisation and perpetration. Child Soc 2011;25:59-72.

55. Mishna F, Cook C, Gadalla T, et al. Cyberbullying behaviors among middle and high school students. Am J Orthopsychiatry 2010;80:362-74.
56. Ortega R, Elipe P, Mora-Merchán JA, et al. The emotional impact on victims of traditional bullying and cyberbullying: a study of Spanish adolescents. J Psychol 2009;217:197-204.

57. Mishna F, Saini M, Solomon S. Ongoing and online: children and youth's perceptions of cyber bullying. Child Youth Serv Rev 2009;31:1222-8.

58. Klein DA, Goldenring J, Adelman WP. HEEADSSS 3.0:

The psychosocial interview for adolescents updated for a new century fueled by media [Internet]. Vol. 1, Contemporary Pediatrics. 2014:1-14. http://contemporarypediatrics.

modernmedicine.com/contemporary-pediatrics/news/probingscars-how-ask-essential-questions?page=full (accessed 9 Oct 2016). 